\title{
АДМИНИСТРАТИВНО-ПРАВОВЫЕ АКТЫ СУБЪЕКТОВ РОССИЙСКОЙ ФЕДЕРАЦИИ КАК ОСОБЫЕ ИСТОЧНИКИ РЕГИОНАЛЬНОГО ЗАКОНОДАТЕЛЬСТВА В СФЕРЕ АДМИНИСТРАТИВНЫХ ПРАВОНАРУШЕНИЙ В ДАЛЬНЕВОСТОЧНОМ ФЕДЕРАЛЬНОМ ОКРУГЕ
}

\section{ADMINISTRATIVE AND LEGAL ACTS \\ OF THE SUBJECTS OF THE RUSSIAN FEDERATION AS SPECIAL SOURCES OF REGIONAL LEGISLATION IN THE FIELD OF ADMINISTRATIVE OFFENSES IN THE FAR EASTERN FEDERAL DISTRICT}

N. Rud

Summary. The main administrative and legal acts of the subjects of the Russian Federation on the example of the Far Eastern Federal District are discussed in this article. In paper the current administrative legislation of 11 constituent entities of the Russian Federation is examined. The author identifies the main features in the structure of laws (codes) of the subjects of the Russian Federation, the order of adoption. In the process of work, the author uses the following methods: analysis, comparison.

Keywords: legislation, regulatory legal act, administrative responsibility, constitutions and charters, laws and codes, subject of the Russian Federation.
B ведении Российской Федерации находятся: общие положения и принципы административного законодательства; перечень наказаний и правил их применения в административной сфере; установление административной ответственности по вопросам, соблюдения федерального законодательства, в т.ч. в области обеспечения производства, исполнения постановлений о наложении административных задержаний.

В связи с принятием Конституции Российской Федерации [1], в нашей стране закрепилась трёхзвенная система источников административного законодательства. На федеральном уровне - Конституция РФ и федеральное административное законодательство (особое место занимает Кодекс об административных правонарушениях РФ) [2]; на уровне субъектов - Конституции (уставы) субъектов РФ и региональное административное законодательство (по вопросам совместного и ис-
Рудь Нина Ивановна

Аспирант, ФГБОУВО «Тихоокеанский государственный университет» whale55555@mail.ru

Аннотация. В данной статье рассматриваются основные административно-правовые акты субъектов Российской Федерации на примере Дальневосточного федерального округа. В работе исследуется административное законодательство 11 субъектов Российской Федерации, действующее в настоящее время. Автор выявляет основные особенности в структуре законов (кодексов) субъектов РФ, порядке принятия. В процессе работы автор использует методы: анализ, сравнение.

Ключевые слова: законодательство, нормативно-правовой акт, административная ответственность, конституции и уставы, законы и кодексы, субъект Российской Федерации. ключительного ведения субъектов РФ); уровень муниципальных образований - нормативно-правовые акты соответствующих муниципалитетов.

Вопрос о месте и роли конституции (устава) субъекта РФ в системе источников административного права уже давно тревожит умы ученых. С одной стороны, Конституция РФ содержит довольно мало упоминаний о его основных свойствах. Часть 2 статьи 4 Конституции закрепляет верховенство федеральных законов в РФ, кроме этого, часть 1 статьи 15 говорит о недопустимости возникновения противоречий между законами (и иными актами) и положениями самой Конституции Российской Федерации [1]. А с другой стороны, сами конституции (уставы) регионов вбирают в себя все юридические признаки, свойственные для нашего Основного законы страны. Несмотря на схожесть некоторых положений конституций и уставов субъектов [4-14], все они долж- 
ны соответствовать Конституции Российской Федерации. Положения Конституционного суда РФ должны учитываться органами государственной власти каждого отдельного региона при разработке ими собственных нормативных правовых актов, чтобы не допустить возможных неточностей и противоречий.

Высшее должностное лицо субъекта имеет право принимать нормативные правовые акты в данной сфере. К ним относятся: указы, постановления, распоряжения, издаваемые руководителем высшего исполнительного органа государственной власти субъекта РФ [3].

Давайте рассмотрим подробнее административные нормативные правовые акты субъектов Российской Федерации в Дальневосточном Федеральном округе.

Закон субъекта РФ - это следующее звено в структуре административных источников нормативных правовых актов региона. Бывают обычные законы, кодексы или конституционные. Все они не должны противоречить не только конституции (уставу) субъекта Российской Федерации, но и конституции РФ, федеральным законам.

Занимая уникальное положение, конституция (устав) субъекта, одновременно и источник административного права в РФ и основной закон в своем субъекте.

Из 11 регионов ДФО только в двух (Хабаровском крае и Республике Саха (Якутия) имеются кодифицированные акты [22,25], в остальных 8-Законы об административных правонарушениях [16-21,23,24], в Амурской области - Закон об административной ответственности [15].

Итак, Конституция РФ закрепила следующие источники права субъектов РФ (в т.ч. и административного): а) конституции и законы республик в составе РФ; б) уставы краев, областей, городов федерального значения, автономной области, автономных округов; в) законы и другие акты субъектов Федерации. Также к ним можно отнести договоры и соглашения (как международные, так и национальные).

Каждый из законов (кодексов) имеет свой уникальный характер, поскольку разные регионы обладают специфическими признаками (географическими, экономическими, социальными и т.д.). Как отмечает Другов Я.А. в своей статье: «выделяют две формы принятия указанных кодексов: 1) кодексы принимаются как самостоятельные акты со своим номером и датой принятия; 2) кодексы принимаются законом субъекта РФ, где все реквизиты кодекса относятся к данному закону» [29]. Это высказывание находит свое подтверждение среди административных законов и кодексов дальневосточно- го региона. Например, Закон Республики Саха (Якутия) от 14 октября 2009 г. 726-3 N337-IV «О Кодексе Республики Саха (Якутия) об административных правонарушениях» [22] имеет реквизиты, относящиеся непосредственно к самому закону (второй описанный случай), а Кодекс Хабаровского края об административных правонарушениях принят Законодательной думой Хабаровского края 24 июня 2009 года № 256 (первый случай) [25]. Эти примеры показывают, как разнообразно применяется юридическая техника в рамках одного округа России.

Как отмечалось ранее, главенствующая роль среди источников административного права субъектов РФ принадлежит конституциям (уставам) субъекта РФ, которые имеют высшую юридическую силу в структуре актов определенного субъекта. Они обладают всеми чертами, присущими таким источникам - точное определение прав и обязанностей участников правовых отношений, обязательность по отношению к широкому кругу лиц, известность для сторон административных правоотношений.

Конституция (устав) субъекта РФ, как правило, самостоятельно регулирует законодательную деятельность региона, однако в некоторых субъектах есть законы (кодексы) о нормативных правовых актах на этих территориях. Проанализировав законодательство регионов Дальневосточного федерального округа, можно отметить только три субъекта, где имеются подобные акты. В Забайкальском крае, в Республике Саха (Якутия) - это законы[26,27], а в Чукотском автономном округе - кодекс [28]. Они определяют общие положения и используемые основные понятия, систему и виды нормативных правовых актов, порядок подготовки, рассмотрения и принятия этих актов, правила юридической техники. Кроме этого, Кодекс о нормативных правовых актах Чукотского автономного округа содержит Приложения, в котором очень подробно описаны: особенности языка актов, требования к структуре законопроектов, требования к структуре иных нормативных правовых актов, порядок употребления ссылок и другие особенности работы с правовыми актами в Чукотском автономном округе.

Кроме этого, законодательные органы субъекта издают законодательные акты, подзаконные акты (в виде постановлений - регламенты, положения); исполнительные органы государственной власти субъекта РФ принимают административные правовые акты по вопросам управленческой деятельности, а также изменения или отмены норм административного права.

Регионы России обладают правом самостоятельного законотворчества. Часть 2 статьи 5 Конституции РФ гласит: «Республика (государство) имеет свою конституцию и законодательство. Край, область, город феде- 
рального значения, автономная область, автономный округ имеет свой устав и законодательство». В соответствии с положениями статьи 76 Основного закона РФ нормативные правовые акты субъекта РФ, которые изданы вне пределов ведения Российской Федерации и ее совместного ведения с субъектами РФ, занимают более высокое положение нежели, чем акты федеральных органов власти.

Согласно части 1 статьи 72 Конституции Российской Федерации определяется круг вопросов, по которым Российская Федерация и ее субъекты ведут совместное ведение. В частности, административное, административно-процессуальное законодательство относится к таким вопросам [1].

Стоит отметить, что еще одним способом определения полномочий органов государственной власти субъектов является договорной. Договора о разграничении полномочий могут быть заключены, если существуют географические, экономические и специфические черты региона. Данное положение предусмотрено частью 1 статьи 26.7 Федерального закона «Об общих принципах организации законодательных (представительных) и исполнительных органов государственной власти субъектов Российской Федерации» от 6 октября 1999 г. № 184Ф3 [3].

Субъекты РФ регулируют административные правоотношения посредством издания собственных законов, в случае если они находятся вне пределов ведения самой федерации.

Период принятия административных нормативных правовых актов (кодексов и законов) в регионах Дальневосточного федерального округа - 2004-2011 гг.

Как правило, каждый кодекс состоит из нескольких частей: общей, особенной и специальной (органы - подведомственность, производство и исполнение). В большинстве кодексов (законов) этого округа структура одинакова. Исключением является Закон Сахалинской области об административных правонарушениях, в котором отсутствует Общая часть [23]. Здесь законодатель сразу перечисляет виды административных взысканий и административных правонарушений. Также, этот Закон не содержит никаких иных признаков, характерных для общей части подобных актов.

Другие законы (кодексы) субъектов РФ в этом округе в Общей части закрепляют общие положения и принципы законодательства, основные термины, круг лиц, привлекаемых к административной ответственности, «подведомственность дел об административных правонарушениях, виды административных наказаний и дру- гие положения о привлечении виновного лица к административной ответственности» [30].

Как правило, Особенная часть не выделяется в качестве самостоятельного раздела. Ни в одном административном кодексе (законе) из представленных дальневосточных субъектов эта часть не закреплена в качестве раздела (подраздела).

Стоит отметить, что внутренняя структура этих административных нормативных правовых актов тоже весь различна.

Во-первых, количество глав в каждом законе (кодексе) в среднем около 9. Наименьшее количество в акте Забайкальского края - 4 [17], а наибольшее в Республике Саха (Якутия) - 16 [22].

Во-вторых, расположение глав в соответствии с их содержанием также может не совпадать. Большинство законов (кодексов) дальневосточных регионов построены по структуре Кодекса об административных правонарушениях Российской Федерации. Однако Кодекс об административных правонарушениях Хабаровского края [25] и Закон об административных правонарушениях Республики Бурятия [21] содержат главы о должностных лицах, уполномоченных составлять соответствующие протоколы в случае совершения административного правонарушения, и эти главы находятся сразу после общих положений. По мнению автора статьи, такое положение не совсем удачно, поскольку еще не перечислены составы правонарушений. Подходящее место в структуре законов (кодексов) - после перечисления составов административных правонарушений.

В-третьих, имеются и иные различия в некоторых кодексах (законах):

- отсутствие Главы «Заключительные положения» [15];

- наличие Главы «Подведомственность» $[15,19] ;$

- наличие дополнительных Приложений [19,23,25];

- наличие отдельных глав, посвященных административным комиссиям или коллегиям, а также порядок их создания и деятельности $[18,20]$.

Особенность кодексов - это систематизация по видам правоотношений, которые урегулированы высшим административным правовым актом данного субъекта (применительно к иерархии административных источников, издаваемых на этой территории региона). Можно выделить следующие составы правонарушений:

1. правонарушения, посягающие на права граждан и здоровье населения;

2. правонарушения, посягающие на общественный порядок и общественную безопасность; 
3. правонарушения в области охраны окружающей среды и природопользования;

4. правонарушения в области обращения с животными;

5. правонарушения в области землепользования, градостроительства и благоустройства и эксплуатации зданий в районах вечной мерзлоты;

6. правонарушения в сфере управления имуществом, находящимся в государственной собственности субъекта или муниципальной собственности;

7. правонарушения на транспорте;

8. правонарушения в области предпринимательской деятельности;

9. правонарушения в области охраны и использования объектов культурного наследия (памятников истории и культуры) регионального и местного (муниципального) значения, их территорий и зон охраны;

10. правонарушения, посягающие на институты государственной власти и местного самоуправления.

Данный перечень не является исчерпывающим, поскольку особенности дальневосточных регионов весьма разнообразны. Кодифицированные административные акты субъектов РФ содержат различные составы правонарушений в сфере административной ответственности.

Таким образом, проанализировав основные источники административного права во всех 11 субъектах Дальневосточного федерального округа, можно констатировать, что во всех них приняты соответствующие кодифицированные административные нормативно-правовые акты. Они имеют различное наименование;
Кодекс об административных правонарушениях субъекта РФ; Закон об административной ответственности субъекта РФ; Закон об административных правонарушениях субъекта РФ.

Порядок принятия этих актов тоже различен, что может повлечь за собой некоторые проблемы. Кодексы принимаются как самостоятельные акты или как законы субъекта, в то время как административные акты об административных правонарушениях тоже принимаются в виде законов. Может возникнуть коллизия: будет ли считаться Кодекс принятый как закон субъекта полноценным кодексом со всеми, присущими для него признаками, или он всё же будет считаться Законом, обладая признаками последнего.

Некоторые субъекты РФ очень подробно описывают все составы возможных правонарушений, забывая включить в структуру кодекса (закона) неотъемлемые составные элементы (общая часть, заключительные положения).

Различие в построении самого кодифицированного административного акта, тоже может вызвать неоднозначное понимание его содержания (изменение порядка глав).

Конституция (устав) субъекта РФ являются основополагающими источниками административного законодательства на территории определенного субъекта. Все последующие нормативные правовые акты, в том числе и в административной сфере, не должны противоречить не только им, но и Конституции Российской Федерации, а также федеральному законодательству в целом.

\section{ЛИТЕРАТУРА}

1. Конституция Российской Федерации от 12.12.1993 г. (последняя редакция). URL: http://www.consultant.ru/document/cons_doc_LAW_28399/ (дата 0бращения: 26.12.2020).

2. Кодекс Российской Федерации 06 административных правонарушениях от 30.12.2001 г. № 105-Ф3 (последняя редакция). URL: http://www.consultant.ru/ document/cons_doc_LAW_34661/ (дата обращения: 26.12.2020).

3. Федеральный закон «0б общих принципах организации законодательных (представительных) и исполнительных органов государственной власти субъектов Российской Федерации» от 06.10.1999 N184-Ф3 (последняя редакция). URL: http://www.consultant.ru/document/cons_doc_LAW_14058/ (дата 06ращения: 26.12.2020).

4. Конституция Республики Бурятия (принята Верховным Советом Республики Бурятия 22 февраля 1994 г.) (последняя редакция). URL: https://constitution. garant.ru/region/cons_buryat/chapter/10ed0f917186039eb157d3ba4f962ee5/ (дата обращения: 26.12.2020).

5. Конституция (Основной Закон) Республики Саха (Якутия) от 4.04.92 N908-XII (последняя редакция). URL: https://constitution.garant.ru/region/cons_saha/ (дата обращения: 26.12.2020).

6. Устав Еврейской автономной области от 8 октября 1997 г. N40-03 (последняя редакция). URL: https://constitution.garant.ru/region/ustav_evreis/ (дата 06ращения: 26.12.2020).

7. Устав Забайкальского края от 17 февраля 2009 г. N125-33К (последняя редакция). URL: https://constitution.garant.ru/region/ustav_zabaikal/ (дата 0бращения: 26.12.2020).

8. Устав Камчатского края от 4 декабря 2008 г. N141(последняя редакция). URL: https://constitution.garant.ru/region/ustav_kamchat/ (дата 0бращения: 26.12.2020). 
9. Устав Приморского края от 6 октября 1995 г. N14-К3 (последняя редакция). URL: https://constitution.garant.ru/region/ustav_primor/ (дата 0бращения: 26.12.2020).

10. Устав Хабаровского края от 30 ноября 1995 г. N150 (последняя редакция). URL: https://constitution.garant.ru/region/ustav_habar/ (дата 0бращения: 26.12.2020).

11. Устав Сахалинской области от 9 июля 2001 г. N270 (последняя редакция). URL: https://constitution.garant.ru/region/ustav_sahalin/ (дата обращения: 26.12.2020).

12. Устав Чукотского автономного округа от 28 ноября 1997 г. N26-03 (последняя редакция). URL: https://constitution.garant.ru/region/ustav_chukot/ (дата 0бращения: 26.12.2020).

13. Устав (Основной Закон) Амурской области от 13 декабря 1995 г. № 40-03 (последняя редакция). URL: https://www.amurobl.ru/pages/dokumenty/ustavosnovnoy-zakon-amurskoy-oblasti/ (дата обращения: 27.12.2020).

14. Устав (Основной Закон) Магаданской области от 28 декабря 2001 г. N218-03 (последняя редакция). URL: https://constitution.garant.ru/region/ustav_ magadan/ (дата обращения: 26.12.2020).

15. Закон Амурской области «0б административной ответственности в Амурской области» от 30 марта 2007 г. № 319-03 // «Вестник администрации Амурской области», N3, 01.04.2007.

16. Закон Еврейской автономной области «0б административных правонарушениях» от 23 июня 2010 г. № 781-03// «Биробиджанер штерн», N48, 02.07 .2010$.

17. Закон Забайкальского края «0б административных правонарушениях» от 02 июля 2009 г. № 198-33К // «Забайкальский рабочий», N123-124, 06.07.2009.

18. Закон Камчатского края «06 административных правонарушениях» от 19 декабря 2008 г. № 209 // «0фициальные Ведомости», N221-225, 30.12.2008.

19. Закон Магаданской области «06 административных правонарушениях в Магаданской области» от 15 марта 2005 г. № 583-03 // Приложение к газете «Магаданская правда», N28(19399), 16.03.2005.

20. Закон Приморского края «06 административных правонарушениях в Приморском крае» от 05 марта 2007 г. № 44-КЗ // «Ведомости Законодательного Собрания Приморского края», 06.03.2007, N10, «Приморская газета», N17(79), 13.03.2007.

21. Закон Республики Бурятия «0б административных правонарушениях» от 05 мая 2011 г. № 2003-IV // «Бурятия», N79, 07.05.2011, 0фициальный вестник N51, «Собрание законодательства Республики Бурятия», N4-5(145-146), 2011.

22. Закон Республики Саха (Якутия) «Кодекс Республики Саха (Якутия) 06 административных правонарушениях» 0т 14 октября 2009 г. № 726-3 N337-IV // «Якутские ведомости», N66, 11.11.2009, «Ил Тумэн», N44, 13.11.2009, «Сокуоннар. Уураахтар. Дьаһаллар.», N175-178, 19.12.2009.

23. Закон Сахалинской области «0б административных правонарушениях в Сахалинской области» от 29 марта 2004 г. № 490 // «Губернские ведомости», N74-75(2010-2011), 03.04.2004.

24. Закон Чукотского автономного округа «0б административной ответственности за нарушение законов и иных нормативных правовых актов Чукотского автономного округа, нормативных правовых актов органов местного самоуправления в Чукотском автономном округе» от 06 июня 2008 г. № $69-03$ // «Ведомости», N23(350), 12.06.2008.

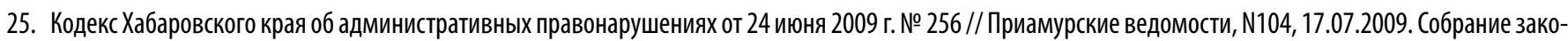
нодательства Хабаровского края, N7 (84), 12.08.2009. Часть 1

26. Закон Забайкальского края «0 нормативных правовых актах Забайкальского края» от 18 декабря 2009 г. № 321-33К // «Забайкальский рабочий», N239242, 21.12.2009.

27. Закон Республики Саха (Якутия) «0 правовых актах органов государственной власти Республики Саха» от 25 декабря 2003 г. № 98-3 N199-ІІІ // «Якутские ведомости», N4, 17.01.2004, «Ил Тумэн», N8, 27.02.2004, «Сокуоннар. Уураахтар. Дьаһаллар.», N18, 03.04.2004.

28. Закон Чукотского автономного округа «Кодекс 0 Нормативных Правовых Актах Чукотского Автономного Округа» от 24 февраля 2009 г. № 25-03 // «Ведомости», N8/3(386/3), 27.02.2009.

29. Другов А.Я. Кодекс субъекта Российской Федерации об административных правонарушениях как результат систематизации законодательства об административной ответственности // Вопросы конституционного, муниципального, административного, финансового права. Сибирский юридический вестник. 2016. № 1 (72). С. 37-42.

30. Сперанский С.Б. Проблемы реализации полномочий субъектов Российской Федерации при разработке законодательства об административных правонарушениях // Сборник трудов аспирантов и соискателей-юристов. Вып. 3 /отв. Ред. А.В. Петров. Н. Новгород, 2003. С. 139.

31. Тихомиров Ю.А. Правовые акты: учеб.-методич. и справ. Пособие / Ю.А. Тихомиров, И.В. Котелевская. М., 1999. С. 74.

() Рудь Нина Ивановна ( whale55555@mail.ru).

Журнал «Современная наука: актуальные проблемы теории и практики» 